\title{
Ontwikkeling van referentiegegevens voor verzuimduur naar diagnose
}

\author{
J.F. Ybema, T. Schaafsma
}

\section{SAMENVATTING}

Dit artikel beschrijft de ontwikkeling van referentiegegevens voor de verzuimduur naar diagnose. Daarbij worden twee bronnen vergeleken: (I) gegevens van het Peilstation die zijn aangeleverd door getrainde bedrijfsartsen over een beperkt aantal verzuimgevallen; en (2) verzuimgegevens uit de registraties van arbodiensten over grote aantallen verzuimgegevens waarvan de kwaliteit onbekend is. In dit onderzoek staat centraal in hoeverre gegevens van het Peilstation representatief zijn voor alle verzuimgevallen en in hoeverre de arbodienstgegevens bruikbaar zijn om referentiegegevens op te baseren. Deze vragen worden beantwoord door koppeling van de beide databestanden op individueel niveau, waarbij de overeenkomsten en discrepanties in diagnose en verzuimduur worden onderzocht. De conclusie uit het onderzoek is dat de gegevens van het Peilstation in voldoende mate representatief zijn.

Verder zijn de arbodienstdata bruikbaar om referentiegegevens voor verzuimduur naar diagnose op te baseren na weging om te corrigeren voor selectieve toekenning van diagnoses.

Wat zou het mooi zijn als we aan het begin van een verzuim zouden kunnen voorspellen hoe lang het gaat duren. Bedrijfsartsen kunnen op basis daarvan het plan van aanpak aanpassen, verzekeraars krijgen een inschatting van de loonkosten die zij moeten vergoeden, werkgevers kunnen op basis van een goede voorspelling het werk van de persoon herverdelen of een vervanger inschakelen en de werknemers krijgen meer zekerheid over de termijn waarop zij weer kunnen werken. Voor individuele verzuimgevallen zal het niet mogelijk zijn dergelijke voorspellingen te doen. De duur van het individuele verzuim is en blijft immers afhankelijk van tal van factoren die niet allemaal goed te modelleren zijn.

Wel kunnen we een indicatie krijgen van de verwachte verzuimduur door per diagnose te onderzoeken wat het gemiddelde en de spreiding in de verzuimduur is. Op basis van dergelijke gegevens kan van een individueel verzuimgeval bepaald worden of de werknemer relatief snel of juist langzaam het werk hervat. In de VS zijn diverse richtlijnen voor de verzuimduur beschikbaar. ${ }^{\text {. }}$

REFERENTIE-

GEGEVENS,

VERZUIMDUUR,

DIAGNOSE,

VALIDATIE
Een belangrijke daarvan is de Medical Disability Advisor (MDA), ${ }^{2}$ waarin voor circa Iooo diagnoses (ICD-9) een beschrijving van de diagnostiek, behandeling en prognose wordt gegeven. Voor ruim 200 aandoeningen worden bovendien nor- matieve data gegeven voor de verwachte verzuimduur. Deze Amerikaanse gegevens zijn niet zonder meer te vertalen naar de Nederlandse situatie door grote verschillen in wetgeving en sociale zekerheid. In het algemeen is de verzuimduur in Nederland hoger dan in de Verenigde Staten. ${ }^{3.4}$ Er zijn in Nederland op dit moment weinig gegevens beschikbaar over de verzuimduur naar diagnose. De Nationale Verzuimstatistiek van CBS5 bevat bijvoorbeeld geen medische gegevens. Mede daarom heeft STECR het Laboretum opgezet.

Het Laboretum is een Nederlandse versie van de MDA en bestaat uit twee onderdelen. Een compacte beschrijving van de meest recente kennis van diagnostiek, behandeling en re-integratie en een databank met referentiegegevens voor de verzuimduur en WIA-instroom per diagnose. Sinds de zomer van 2008 zijn ongeveer 40 ziektebeelden opgenomen in het Laboretum.

In dit artikel beschrijven we hoe we tot de referentiegegevens voor verzuimduur gekomen zijn en hoe we onderzoek gedaan hebben naar de validiteit van die referentiegegevens. In een volgend artikel zullen we nagaan in hoeverre we de verzuimduur kunnen voorspellen op basis van onder meer de diagnose, werkkenmerken, kenmerken van de begeleiding door de bedrijfsarts en factoren die de werkhervatting belemmeren.

De referentiegegevens die gebruikt worden voor het Laboretum, zijn afkomstig van twee bronnen. De eerste bron is het Peilstation. In 2004 en 2005 hebben 70 bedrijfsartsen gericht gegevens verzameld van door hen begeleide verzuimgevallen. De tweede bron betreft de databestanden van vier grote arbodiensten over verzuimgevallen die in dezelfde periode zijn afgesloten als die in het Peilstation. Deze databestanden bevatten in totaal ruim 4,2 miljoen verzuimgegevens.

We hebben beide databronnen gebruikt voor een kruisvalidatie. Een vraag bij de gegevens van het Peilstation is hoe representatief deze gegevens zijn. Het is mogelijk dat de deelnemende bedrijfsartsen een selectie van de verzuimgevallen waar- 
voor zij verantwoordelijk zijn, hebben gemeld aan het Peilstation. Bovendien is het mogelijk dat deelnemende bedrijfsartsen een selecte groep vormen die niet representatief is voor de totale groep bedrijfsartsen in Nederland. Dit beoordelen we aan de hand van de arbodienstgegevens. We onderzoeken de volgende vragen:

1. Hoe representatief zijn de Peilstationgegevens?

a. Melden bedrijfsartsen een selectie van de gevallen die zij hebben?

b. Verschillen meldende van niet-meldende bedrijfsartsen?

Vervolgens hebben we gekeken of de gegevens van de arbodiensten vergelijkbaar zijn met de gegevens van het Peilstation en zo gebruikt kunnen worden voor het genereren van goede referentiegegevens voor verzuimduur per diagnose. Hierbij gebruiken we de diagnose en de verzuimduur in het Peilstation als 'gouden standaard'. Het Peilstation bevat door de manier van verzamelen kwalitatief goede data waarbij een juiste diagnosecode is opgenomen en de verzuimgegevens op een zorgvuldige wijze zijn ingevuld. Dit leidt tot de volgende vragen:

2. Zijn de arbodienstgegevens bruikbaar om verzuimreferentiegegevens te genereren?

a. In hoeverre komt de verzuimduur in Peilstation- en arbodienstdata overeen?

b. In hoeverre komt de diagnose in Peilstation- en arbodienstdata overeen?

c. Is de toekenning van diagnosecodes afhankelijk van de verzuimduur?

\section{METHODE}

In het Peilstation zijn in de periode van I mei 2004 tot 3I december 2005 verzuimgegevens verzameld over 4I96 verzuimgevallen door 70 bedrijfsartsen. Deze bedrijfsartsen hebben zichzelf aangemeld na een oproep van STECR, en waren afkomstig uit bijna alle grote arbodiensten. Ook een aantal zelfstandige bedrijfsartsen heeft deelgenomen. Na aanmelding hebben de bedrijfsartsen een training van een halve dag gevolgd. Bij het afsluiten van een verzuimgeval vulde de bedrijfsarts in wat de diagnosecode (volgens CAS) was, op welke datum het verzuim begon, wanneer de werknemer voor het eerst het werk gedeeltelijk hervatte, wanneer de werknemer voor 50\% of meer het werk hervatte en wanneer de werknemer medisch gezien hersteld was. De instructie was dat de bedrijfartsen alle begeleide verzuimgevallen van 4 weken of langer zouden melden. De gemelde gevallen hebben allemaal een volledige diagnosecode en een geldige verzuimduur. Naast deze verzuimgegevens werden ook inhoudelijke gegevens over de begeleiding verzameld. Deze gegevens worden in dit artikel niet gebruikt.

Daarnaast hebben we van vier grote arbodiensten alle verzuimgevallen die zijn afgesloten in dezelfde periode van I mei 2004 tot 3I december 2005 ontvangen, dit waren 4,2 miljoen verzuimgevallen. Deze data waren veel minder volledig, in veel gevallen ontbrak bijvoorbeeld de CASdiagnosecode. Volgens CBS telde de beroepsbevolking in 2005 circa 6 miljoen werknemers en was de verzuimfrequentie $0,99 .{ }^{5}$ Over de periode van ons onderzoek komt dit overeen met circa Io miljoen ziekmeldingen. Onze datagroep vertegenwoordigt dus ruim 40\% van alle ziekmeldingen. De vier arbodiensten zijn actief in alle bedrijfssectoren.

Om vergelijking met de gegevens van het Peilstation mogelijk te maken was bewerking van deze data noodzakelijk. Daarbij zijn individuele verzuimgevallen in het Peilstation gekoppeld aan individuele verzuimgevallen in de arbodienstgegevens. Daarbij is gekoppeld op geboortedatum, eerste ziektedag en bedrijfsartscode. Niet alle meldingen in het Peilstation konden worden gekoppeld aan arbodienstgegevens. Dit komt doordat niet alle arbodiensten databestanden hebben aangeleverd. Verder blijkt dat in de arbodienstgegevens soms een andere bedrijfsarts geregistreerd staat dan de bedrijfsarts die de verzuimende werknemer daadwerkelijk heeft begeleid (en het verzuimgeval meldt in het Peilstation). Ten slotte zullen er soms fouten staan in de geboortedatum of de eerste ziektedag in ofwel de Peilstation- ofwel de arbodienstdata.

In tabel I is weergegeven hoeveel verzuimgevallen de Peilstation- en de arbodienstgegevens bevatten en welk deel daarvan gekoppeld kon worden. In totaal konden er II33 van de 4I96 ver-

I Er zijn referentiegegevens ontwikkeld om de normale verzuimduur per diagnose vast te stellen.

I Hierbij is gebruikgemaakt van twee databronnen die onderling vergeleken zijn: gegevens van het Peilstation en die van vier grote arbodiensten.

I De resulterende referentiegegevens geven een goed beeld van de verzuimduur die in Nederland verwacht mag worden bij specifieke diagnoses. 


\begin{tabular}{|c|c|c|}
\hline \multicolumn{3}{|c|}{$\begin{array}{l}\text { Tabel } 1 \\
\text { Het aantal verzuimgevallen in Peilstation- en in de arbodienstdata }\end{array}$} \\
\hline & Peilstation & Arbodiensten \\
\hline \multicolumn{3}{|l|}{ Totale databestand } \\
\hline aantal arbodiensten & 16 & 4 \\
\hline aantal bedrijfsartsen & 70 & 1.500 \\
\hline aantal verzuimgevallen & 4.196 & 4.236 .323 \\
\hline \multicolumn{3}{|l|}{ Verzuim van 43 dagen of meer } \\
\hline aantal bedrijfsartsen & 68 & 1.448 \\
\hline aantal verzuimgevallen & 2.734 & 465.244 \\
\hline \multicolumn{3}{|l|}{ Beschikbaar voor koppeling } \\
\hline aantal arbodiensten & 4 & 4 \\
\hline aantal bedrijfsartsen & 31 & 31 \\
\hline aantal verzuimgevallen & 2.048 & 122.415 \\
\hline aantal verzuimgevallen van 43 dagen of meer & 1.400 & 13.166 \\
\hline \multicolumn{3}{|l|}{ Uitkomst koppeling } \\
\hline aantal gekoppelde verzuimgevallen & 1.133 & 1.133 \\
\hline aantal niet-gekoppelde verzuimgevallen & 915 & 121.282 \\
\hline \multicolumn{3}{|l|}{ Uitkomst koppeling 43 dagen en meer } \\
\hline aantal gekoppelde verzuimgevallen & 780 & 774 \\
\hline aantal niet-gekoppelde verzuimgevallen & 620 & 12.392 \\
\hline
\end{tabular}

zuimgevallen in het Peilstation van 3I verschillende bedrijfsartsen van de vier arbodiensten worden gekoppeld aan identieke gevallen in de arbodienstdata. Daarnaast hadden deze 3I bedrijfsartsen 9I5 meldingen in het Peilstation die niet gekoppeld konden worden. Volgens de arbodienstdata waren deze 3I bedrijfsartsen verantwoordelijk voor I 2 I.282 verzuimgevallen die niet gemeld waren aan het Peilstation. Het grootste deel hiervan betrof kortdurende verzuimgevallen die niet door een bedrijfsarts waren gezien.

Volgens de Wet verbetering poortwachter (Wvp) moeten bedrijfsartsen binnen 6 weken na de eerste verzuimdag een probleemanalyse maken. We nemen aan dat bedrijfsartsen een zieke werknemer na 6 weken verzuim in ieder geval heeft gezien en in principe een diagnose heeft gesteld. In de referentiegegevens voor verzuimduur per diagnose maken we daarom steeds gebruik van verzuimgevallen van 43 dagen of langer. Ook deze kruisvalidatie beperken we tot verzuim met een duur van 43 dagen of langer. De 3 I bedrijfsartsen met gekoppelde verzuimgevallen zijn volgens de arbodienstdata verantwoordelijk voor I3.I66 verzuimgevallen van 43 dagen of meer, waarvan er 774 aan het Peilstation zijn gemeld. In totaal bevatten de arbodienstdata 465.244 verzuimgevallen van 43 dagen of meer. Volgens het Peilstation hebben de 3I bedrijfsartsen I400 verzuimgevallen gemeld van 43 dagen of meer, waarvan er 780 verzuimgevallen gekoppeld zijn aan verzuimgevallen in de arbodienstdata.

\section{Analyses}

We analyseren de data met SPSS I4. Bij vraag Ia en $\mathrm{Ib}$ onderzoeken we verschillen in verzuim- duur en diagnose in de arbodienstdata tussen wel of niet gemelde verzuimgevallen (vraag ra) en tussen wel of niet deelnemende artsen (vraag Ib). Bij vraag ra maken we gebruik van een $t$-toest om verschillen in gemiddelde verzuimduur te toetsen. Verzuimduur is echter geen normaal verdeelde variabele, maar heeft een sterk positief scheve verdeling. Dit betekent dat aan de voorwaarden voor zo'n parametrische toets strikt genomen niet is voldaan. Daarom rapporteren we ook de mediaan voor verzuimduur, die aangeeft wanneer 50\% van de verzuimgevallen is hersteld en een niet-parametrische toets voor het verschil in verzuimduur, de Mann-Whitney Utoets voor ongepaarde waarnemingen. Bij beantwoording van vraag Ib laten we significantietoetsing achterwege omdat dit zeer grote aantallen verzuimgevallen betreft. Ieder waarneembaar verschil is dan significant. Bij vraag $2 a$ vergelijken we de verzuimduur in de Peilstationdata met die in de arbodienstdata van de gekoppelde verzuimgevallen. Dit doen we zowel met een parametrische $t$-toets als met een niet-parametrische Wilcoxon-rangtoets voor gepaarde waarnemingen. Verschillen in diagnoses (bij vraag Ia en $2 b$ ) worden getoetst met een chikwadraattoets.

\section{RESULTATEN}

Vraag 1 a: Melden bedrijfsartsen een selectie van de gevallen die zij hebben? We onderzoeken hier of de verzuimduur en de toegekende diagnosecodes in de arbodienstgegevens overeenkomen voor de verzuimgevallen die de deelnemende bedrijfsartsen melden aan het Peilstation en de verzuimgevallen die zij niet melden. In de eerste twee kolommen van tabel 2 is te zien dat de gemiddelde verzuimduur bij gemelde verzuimgevallen 3 dagen langer is dan bij niet-gemelde verzuimgevallen. Dit verschil is echter niet significant, $t$ (I3.I64) $=0,65, n s$. Wanneer we de verzuimduur niet-parametrisch toetsen met de Mann-Whitney U-toets, vinden we wel een verschil, $Z=-4,42, p<0,001$. De mediaan geeft aan wanneer 50\% van de verzuimgevallen is hervat. Het verschil in de mediaan laat zien dat gemelde gevallen doorgaans langer duren dan niet-gemelde gevallen.

Verder is nagegaan of de diagnose verschilt bij gemelde en niet-gemelde gevallen. Dat blijkt het geval te zijn. Verzuimgevallen die zijn gemeld aan het Peilstation, hebben veel vaker een volledige diagnose in de arbodienstdata dan verzuimgevallen die niet worden gemeld aan het Peilstation, $\chi^{2}(2)=269,3, p<0,00$ I. Wanneer we alleen verzuimgevallen met een volledige diag- 
nosecode beschouwen, dan blijkt dat verzuimgevallen die worden gemeld aan het Peilstation relatief vaak een psychische diagnose betreffen, $\chi^{2}(2)=23,0, p<0,00 I$.

Vraag 1 b: Verschillen meldende van niet-meldende bedrijfsartsen?

Vervolgens is nagegaan of de bedrijfsartsen die verzuimgevallen aan het Peilstation hebben gemeld, verschillen van hun collega's die niet deelnemen aan het Peilstation. Daartoe hebben we de verzuimduur en de diagnoses van deelnemende en niet-deelnemende bedrijfsartsen in de arbodienstdata vergeleken. Dit is weergegeven in de derde en vierde kolom van tabel 2.

Gemiddeld hebben deelnemende bedrijfsartsen een iets kortere verzuimduur dan niet-deelnemende bedrijfsartsen. De mediaan is voor beide groepen echter gelijk, wat suggereert dat het verschil in gemiddelde wellicht vooral komt door uitbijters bij de niet-deelnemende bedrijfsartsen (met een verzuimduur die soms oploopt tot tientallen jaren, wellicht doordat verzuimgevallen in sommige gevallen pas bij ontslag of pensioen administratief worden afgesloten).

Wanneer gekeken wordt naar de diagnosecode, dan blijkt dat de meldende bedrijfsartsen vaker een volledige diagnosecode (I letter, 3 cijfers) opgeven dan niet-meldende bedrijfsartsen. Indien een volledige diagnose wordt gesteld, is de verdeling over de drie hoofdgroepen van diagnoses (L, P, overig) vrijwel gelijk bij meldende en bij niet-meldende bedrijfsartsen.

Vraag 2a: In hoeverre komt

de verzuimdur in Peilstation-

en arbodienstdata overeen?

Bij gekoppelde verzuimgevallen komen de verzuimduur in de Peilstation- en de arbodienstdata niet altijd precies overeen. We selecteren voor de analyses gekoppelde verzuimgevallen die 43 dagen of meer hebben verzuimd volgens de Peilstation- en/of arbodienstgegevens. In tabel 3 is dit weergegeven. Dit betekent dat we van de I 33 gekoppelde verzuimgevallen er 325 met kort verzuim volgens beide bronnen uitsluiten en analyses doen op 805 verzuimgevallen (drie gevallen hebben missende waarden in verzuimduur).

In tabel 4 is weergegeven wat de verzuimduur is in de arbodienstdata en in de gegevens van het Peilstation voor de 805 gekoppelde verzuimgevallen. Uit de tabel blijkt dat de verzuimduur

\begin{tabular}{|c|c|c|c|c|}
\hline \multicolumn{5}{|c|}{$\begin{array}{l}\text { Tabel } 2 \\
\text { Het aantal verzuimgevallen in Peilstation- en in de arbo }\end{array}$} \\
\hline Deelname aan Peilstation? & \multicolumn{3}{|l|}{ Ja } & \multirow{2}{*}{$\begin{array}{l}\text { Nee } \\
\text { Totaal }\end{array}$} \\
\hline Gemelde verzuimgevallen? & Ja & Nee & Totaal & \\
\hline Aantal artsen & 31 & 31 & 31 & 1.422 \\
\hline Aantal verzuimgevallen & 774 & 12.392 & 13.166 & 452.078 \\
\hline \multicolumn{5}{|l|}{ Verzuimduur (in dagen) } \\
\hline minimum & 43 & 43 & 43 & 43 \\
\hline maximum & 1.127 & 2.400 & 2.400 & 10.232 \\
\hline mediaan & 126 & 111 & 112 & 112 \\
\hline gemiddelde & 167,81 & 164,85 & 165,02 & 169,58 \\
\hline standaarddeviatie & 142,18 & 177,37 & 175,49 & 188,81 \\
\hline \multicolumn{5}{|l|}{ Diagnose aanwezig } \\
\hline geen CAS-code & $4,7 \%$ & $27,1 \%$ & $25,8 \%$ & $34,9 \%$ \\
\hline alleen hoofdgroep (1 letter) & $2,3 \%$ & $8,6 \%$ & $8,3 \%$ & $12,4 \%$ \\
\hline volledige CAS-code ( 1 letter, 3 cijfers) & $93,0 \%$ & $64,2 \%$ & $65,9 \%$ & $52,7 \%$ \\
\hline \multicolumn{5}{|c|}{ Diagnosecode (indien volledige CAS-code) } \\
\hline bewegingsapparaat (alle L-codes) & $31,8 \%$ & $34,9 \%$ & $34,6 \%$ & $34,8 \%$ \\
\hline psychisch (alle P-codes) & $37,1 \%$ & $28,7 \%$ & $29,4 \%$ & $28,8 \%$ \\
\hline overig (alle overige codes) & $31,1 \%$ & $36,5 \%$ & $36,0 \%$ & $36,4 \%$ \\
\hline
\end{tabular}

\begin{tabular}{|c|c|c|c|}
\hline \multicolumn{4}{|c|}{ Tabel 3} \\
\hline \multirow{2}{*}{$\begin{array}{l}\text { Verzuim in } \\
\text { arbodienstdata }\end{array}$} & \multicolumn{3}{|c|}{ Verzuim in Peilstationdata } \\
\hline & Korter dan 43 dagen & 43 dagen of langer & Totaal \\
\hline Korter dan 43 dagen & 325 & 31 & 356 \\
\hline 43 dagen of langer & 25 & 749 & 774 \\
\hline Totaal & 350 & 780 & 1.130 \\
\hline
\end{tabular}

gemiddeld enkele dagen korter is in de Peilstation- dan in de arbodienstdata. Dit is een significant verschil, $t(804)=3,0, p<0,0 I$, Wilcoxon $Z=-4,7, p<$ o,ooI.

Tabel 5 geeft weer in hoeverre de verzuimduur van de 805 verzuimgevallen in Peilstation- en arbodienstgegevens overeenkomen. In bijna 60\% van de gevallen komt deze verzuimduur exact overeen. In $26 \%$ van de gevallen is de verzuimduur langer in de arbodienstdata en in $14 \%$ van de gevallen is de verzuimduur langer in de Peilstationdata. Een mogelijke oorzaak hiervan is dat de deelnemers van het Peilstation gevraagd is naar de datum van medisch herstel, terwijl in de arbodienstdata de datum van volledige werkhervatting is gegeven. In het Peilstation is dus niet gekeken naar de daadwerkelijke datum van de werkhervatting, maar is de door de bedrijfsarts geadviseerde datum genomen.

\begin{tabular}{|lcc|}
\hline \multicolumn{2}{|l|}{$\begin{array}{l}\text { Tabel } \mathbf{4} \\
\text { Verzuimduur van gekoppelde verzuimgevallen in arbodienst- en Peilstationdata }\end{array}$} \\
\hline \multicolumn{2}{l}{ Arbodienstdata } & Peilstationdata \\
\hline$n$ & 805 & 805 \\
Verzuimduur (in dagen) & & \\
$\quad$ minimum & 2 & 17 \\
maximum & 1.127 & 1.134 \\
mediaan & 119 & 112 \\
gemiddelde & 162,25 & 157,53 \\
standaarddeviatie & 142,17 & 133,96 \\
\hline
\end{tabular}




\begin{tabular}{|c|c|c|}
\hline $\begin{array}{l}\text { Tabel } 5 \\
\text { Vergelijking van verzuimduur en diagnose } \\
43 \text { dagen of meer (volgens Peilstation- }\end{array}$ & $\begin{array}{l}\text { ekoppelde } \\
\text { ienstgege }\end{array}$ & ngevallen van \\
\hline & Aantal & $\%$ \\
\hline Vergelijking verzuimduur & & \\
\hline gelijk in Peilstation- en arbodienstdata & 477 & $59,3 \%$ \\
\hline langer in arbodienstdata & 212 & $26,3 \%$ \\
\hline langer in Peilstationdata & 116 & $14,4 \%$ \\
\hline totaal & 805 & $100,0 \%$ \\
\hline CAS-code in arbodienstdata & & \\
\hline geen CAS-code & 47 & $5,8 \%$ \\
\hline alleen hoofdgroep ( 1 letter) & 19 & $2,4 \%$ \\
\hline volledige CAS-code ( 1 letter, 3 cijfers) & 739 & $91,8 \%$ \\
\hline totaal & 805 & $100,0 \%$ \\
\hline Overeenstemming in CAS-code & & \\
\hline Peilstation- en arbodienstdata & & \\
\hline verschillend & 153 & $20,7 \%$ \\
\hline gelijk (zowel letter als 3 cijfers) & 586 & $79,3 \%$ \\
\hline totaal & 739 & $100,0 \%$ \\
\hline Overeenstemming in hoofdgroep & & \\
\hline Peilstation- en arbodienstdata & & \\
\hline verschillend & 47 & $6,4 \%$ \\
\hline gelijk (P, L, overig) & 692 & $93,6 \%$ \\
\hline totaal & 739 & $100,0 \%$ \\
\hline
\end{tabular}

Vraag 2b: In hoeverre komt

de diagnose in Peilstation-

en arbodienstdata overeen?

Bij de 805 gekoppelde verzuimgevallen is nagaan in hoeverre de diagnoses in het Peilstation- en de arbodienstdata onderling overeenkomen. Dit is weergegeven in tabel 5. Indien er een volledige diagnose bekend is in de arbodienstdata, dan komt deze in $79 \%$ van de gevallen exact overeen met die in de data van het Peilstation. Daarnaast komt de hoofdgroep (P, L, overig) overeen in 94\% van de gevallen. $\mathrm{Bij} 2 \mathrm{I} \%$ van de gevallen is er dus sprake van een discrepantie in diagnose tussen de arbodienst- en Peilstationgegevens.

Vraag 2c: Is de toekenning van diagnosecodes afhankelijk van de verzuimduur?

Ook bij verzuim langer dan 6 weken is in de bestanden van de arbodienst niet altijd de diagnosecode ingevuld. Van alle 465.244 verzuimgevallen in de arbodienstdata die minimaal 43 dagen duren, heeft $53 \%$ een volledige diagnosecode. Dit percentage varieert met de verzuimduur. In tabel 6 is het percentage met volledige diagnosecode voor de vier deelnemende arbodiensten weergegeven, uitgesplitst naar het aantal maanden (sinds de ziekmelding) waarbinnen de werkhervatting plaatsvindt. Er is bijvoorbeeld te zien dat bij arbodienst 2 het percentage verzuimgevallen met een volledige diagnosecode (\% CAS) relatief laag is bij verzuim tot 2 maanden (3I\%) en duidelijk toeneemt in de tijd (tot bijvoorbeeld $62 \%$ bij verzuim dat langer dan 2 jaar duurt). Een vergelijkbaar patroon zien we bij arbodienst I en arbodienst 3. Bij arbodienst 4 is het percentage toegekende diagnoses veel hoger en blijft dit vrijwel gelijk over de tijd. Bij het maken van verzuimreferentiegegevens per diagnose maken we uiteraard alleen gebruik van verzuimgevallen met een volledige diagnosecode. Dit betekent dat bij selectie van verzuimgevallen met een volledige diagnose bij arbodiensten I, 2

\begin{tabular}{|c|c|c|c|c|c|c|c|c|}
\hline \multirow{2}{*}{$\begin{array}{l}\text { Uitstroom } \\
\text { in maand }\end{array}$} & \multicolumn{2}{|c|}{ Arbodienst 1} & \multicolumn{2}{|c|}{ Arbodienst 2} & \multicolumn{2}{|c|}{ Arbodienst 3} & \multicolumn{2}{|c|}{ Arbodienst 4} \\
\hline & $\%$ CAS & Weeggewicht & $\%$ CAS & Weeggewicht & $\%$ CAS & Weeggewicht & $\%$ CAS & Weeggewicht \\
\hline 3 & $64,0 \%$ & 1,00 & $37,2 \%$ & 1,10 & $46,8 \%$ & 1,05 & $83,6 \%$ & 1,01 \\
\hline 4 & $54,2 \%$ & 1,18 & $34,2 \%$ & 1,19 & $31,7 \%$ & 1,54 & $84,4 \%$ & 1,00 \\
\hline 5 & $63,4 \%$ & 1,01 & $38,4 \%$ & 1,06 & $41,6 \%$ & 1,18 & $83,3 \%$ & 1,02 \\
\hline 7 & $77,1 \%$ & 0,83 & $47,8 \%$ & 0,85 & $61,7 \%$ & 0,80 & $88,7 \%$ & 0,95 \\
\hline 8 & $77,8 \%$ & 0,82 & $50,4 \%$ & 0,81 & $66,3 \%$ & 0,74 & $88,8 \%$ & 0,95 \\
\hline 9 & $79,5 \%$ & 0,80 & $49,7 \%$ & 0,82 & $68,7 \%$ & 0,71 & $88,2 \%$ & 0,96 \\
\hline 10 & $79,0 \%$ & 0,81 & $51,6 \%$ & 0,79 & $70,2 \%$ & 0,70 & $88,3 \%$ & 0,96 \\
\hline 11 & $79,8 \%$ & 0,80 & $52,7 \%$ & 0,77 & $70,6 \%$ & 0,69 & $90,7 \%$ & 0,93 \\
\hline 12 & $80,3 \%$ & 0,79 & $54,1 \%$ & 0,75 & $74,1 \%$ & 0,66 & $87,1 \%$ & 0,97 \\
\hline 13 & $80,8 \%$ & 0,79 & $54,8 \%$ & 0,74 & $70,2 \%$ & 0,70 & $86,2 \%$ & 0,98 \\
\hline 15 & $82,7 \%$ & 0,77 & $56,1 \%$ & 0,73 & $75,9 \%$ & 0,65 & $89,7 \%$ & 0,94 \\
\hline 16 & $82,1 \%$ & 0,78 & $55,2 \%$ & 0,74 & $78,1 \%$ & 0,63 & $89,0 \%$ & 0,95 \\
\hline 17 & $80,7 \%$ & 0,79 & $58,2 \%$ & 0,70 & $75,0 \%$ & 0,65 & $86,6 \%$ & 0,98 \\
\hline 18 & $82,9 \%$ & 0,77 & $57,5 \%$ & 0,71 & $80,5 \%$ & 0,61 & $90,7 \%$ & 0,93 \\
\hline 19 & $87,0 \%$ & 0,73 & $59,8 \%$ & 0,68 & $73,3 \%$ & 0,67 & $86,7 \%$ & 0,98 \\
\hline 20 & $85,3 \%$ & 0,75 & $59,2 \%$ & 0,69 & $82,7 \%$ & 0,59 & $89,1 \%$ & 0,95 \\
\hline 21 & $79,7 \%$ & 0,80 & $56,4 \%$ & 0,72 & $76,4 \%$ & 0,64 & $89,4 \%$ & 0,95 \\
\hline 22 & $83,5 \%$ & 0,76 & $50,2 \%$ & 0,81 & $79,7 \%$ & 0,62 & $90,0 \%$ & 0,94 \\
\hline 23 & $82,3 \%$ & 0,78 & $56,6 \%$ & 0,72 & $76,4 \%$ & 0,64 & $80,2 \%$ & 1,06 \\
\hline 24 & $83,9 \%$ & 0,76 & $59,3 \%$ & 0,69 & $79,7 \%$ & 0,62 & $89,6 \%$ & 0,95 \\
\hline$>24$ & $83,3 \%$ & 0,77 & $62,0 \%$ & 0,66 & $71,4 \%$ & 0,69 & $85,7 \%$ & 0,99 \\
\hline Gemiddeld & $63,8 \%$ & 1,00 & $40,8 \%$ & 1,00 & $49,0 \%$ & 1,00 & $84,7 \%$ & 1,00 \\
\hline
\end{tabular}


en 3 het relatief kortdurende verzuim wordt onderschat. Bij arbodienst 4 is dat veel minder sterk het geval.

\section{Weging van de arbodienstdata}

Naarmate het verzuim langer duurt, voeren de bedrijfsartsen vaker en beter een volledige diagnosecode in. Dat betekent dat snel herstellende verzuimgevallen vaak onopgemerkt blijven en de uitstroom daardoor onderschat wordt ten opzichte van de feitelijke uitstroom en ten opzichte van de uitstroom in het Peilstation. Om hiervoor te corrigeren, hebben we weeggewichten aangemaakt die per arbodienst voor iedere maand sinds de ziekmelding waarbinnen werkhervatting plaatsvindt een correctie aanbrengt op basis van het percentage verzuimgevallen met een volledige diagnosecode dat in die maand herstelt. Deze weeggewichten zijn weergegeven in tabel 6.

Om het effect van de weging inzichtelijk te maken zijn twee figuren opgenomen. In de figuren zijn de uitstroomcurves van psychische klachten voor het Peilstation en voor de vier arbodiensten weergegeven, waarbij figuur I de ongewogen gegevens en figuur 2 de gewogen gegevens weergeeft. De uitstroomcurves van het Peilstation zijn uiteraard niet gecorrigeerd omdat in het Peilstation alle verzuimgevallen een volledige diagnosecode hebben. Uit de figuren blijkt dat de uitstroomcurves op basis van de verschillende arbodiensten en het Peilstation meer convergeren bij gewogen gegevens dan bij ongewogen gegevens.

\section{BESCHOUWING}

In dit artikel beantwoorden we de volgende vragen:

1. Hoe representatief zijn de Peilstationgegevens?

a. Melden bedrijfsartsen een selectie van de gevallen die zij hebben?

b. Verschillen meldende van niet-meldende bedrijfsartsen?

2. Zijn de arbodienstgegevens bruikbaar om verzuimreferentiegegevens te genereren?

a. In hoeverre komt de verzuimduur in Peilstation- en arbodienstdata overeen?

b. In hoeverre komt de diagnose in Peilstation- en arbodienstdata overeen?

c. Is de toekenning van diagnosecodes afhankelijk van de verzuimduur?

Representativiteit van het Peilstation Wat betreft de eerste onderzoekvraag conclude-

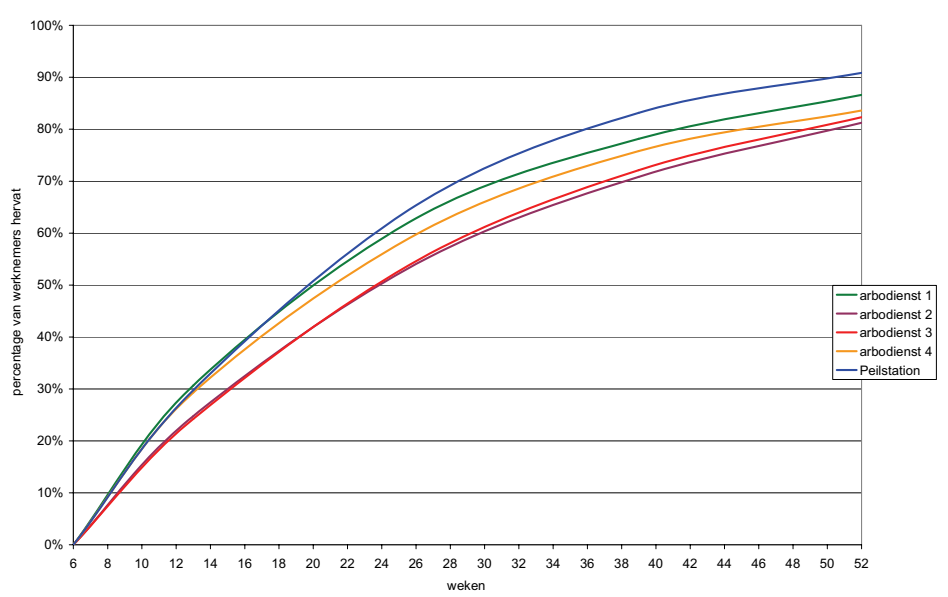

Figuur I. Uitstroomcurve voor volledige werkhervatting bij psychische klachten bij ongewogen data.

ren we dat er sprake is van enige selectie bij de melding van verzuimgevallen aan het Peilstation. Bedrijfsartsen melden relatief wat meer langdurende verzuimgevallen aan het Peilstation. Verder worden verzuimgevallen wegens psychische klachten relatief vaak aan het Peilstation gemeld. Dit laatste leidt echter niet tot vertekening van de verzuimreferentiegegevens, maar alleen tot een verschuiving in de aantallen per diagnose in het Peilstation. Bovendien concluderen we dat meldende bedrijfsartsen vaker een volledige diagnosecode opgeven in de arbodienstregistratie.

Het Peilstation lijkt over de hele linie een redelijk goede representativiteit te hebben. Onze conclusie is dat het Peilstation bruikbaar is voor het maken van referentiegegevens voor de verzuimduur van veelvoorkomende diagnosecodes.

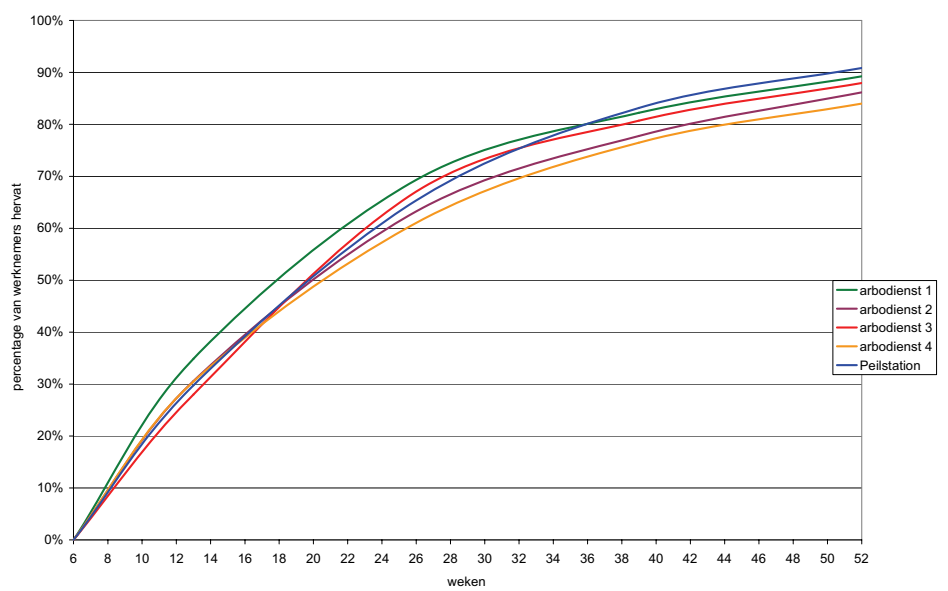

Figuur 2. Uitstroomcurve voor volledige werkhervatting bij psychische klachten bij gewogen data. 
Bruikbaarheid van de arbodienstdata voor referentiegegevens

Indien er een diagnosecode bekend is in de arbodienstgegevens, is er aanzienlijke overeenstemming in verzuimduur en diagnose in de Peilstation- en de arbodienstdata. Niettemin lijkt er bij 2I\% van de verzuimgevallen in de arbodienstdata een onjuiste diagnose te zijn gesteld. Een mogelijke verklaring hiervoor is dat in de arbodienstdata de diagnosecode blijft staan die bij het eerste contact is ingevoerd, ook wanneer er in een later stadium een andere diagnosecode meer van toepassing zou zijn. In het Peilstation wordt de diagnosecode pas bij het afsluiten van het verzuimgeval ingevuld. Uiteraard beperkt dit de bruikbaarheid van de arbodienstdata enigszins en worden de uitstroomcurves vertekend doordat naar schatting gemiddeld een vijfde van de verzuimgevallen een onjuiste diagnosecode heeft. Dit voegt enige 'ruis' toe aan de uitstroomcurves, maar dit leidt niet tot een systematische vertekening.

De bruikbaarheid van de arbodienstdata wordt verder enigszins beperkt door het selectief ontbreken van volledige diagnosecodes. Vooral bij relatief kortdurende verzuimgevallen (korter dan een halfjaar) ontbreekt vaak een volledige diagnosecode. Hierdoor zullen de referentiegegevens op basis van de arbodienstdata een langere verzuimduur laten zien dan die op basis van data van het Peilstation. Deze beperking kan grotendeels worden opgelost door middel van weging waarmee de selectiviteit van het ontbreken van diagnosecodes zo goed mogelijk wordt opgeheven. Het is echter niet uit te sluiten dat voor aandoening $X$ de diagnose pas in een later stadium gesteld wordt, terwijl voor aandoening $Y$ de diagnose wel tijdig wordt gesteld. In dat geval is de voorgestelde weging te zwak voor aandoening $X$ en te sterk voor aandoening $Y$. Met de beschikbare gegevens kunnen we niet bepalen hoe de selectiviteit van het toekennen van diagnoses afhankelijk is van de aard van de diagnose.

Hierbij valt op dat de arbodiensten onderling sterk verschillen in de mate waarin een diagnosecode is opgenomen in de registratie. Ook eerder onderzoek van het $\mathrm{CBS}^{6}$ liet zien dat er grote verschillen zijn tussen de diverse arbodiensten in de mate waarin de diagnose en de oorzaak van het verzuim worden geregistreerd. Deze verschillen tussen arbodiensten geven aan dat het in veel gevallen wel mogelijk is om bij 6 weken verzuim een diagnosecode toe te kennen. Voor goede uitstroomcurves per diagnose zou het wenselijk zijn als de registratiediscipline bij de arbodiensten zou toenemen.

Ten slotte willen we opmerken dat de vier arbodiensten verantwoordelijk zijn voor een aanzienlijk deel van de verzuimgevallen in Nederland en dat zij in alle bedrijfssectoren actief zijn. We gaan ervan uit dat de verzuimgevallen van deze arbodiensten in grote lijnen representatief zijn voor alle verzuimgevallen in Nederland. Er zijn geen redenen om aan te nemen dat opname van andere arbodiensten tot substantieel andere uitstroomcurves zullen leiden. Ondanks de eerder genoemde kanttekeningen hebben we daarom voldoende vertrouwen in de resulterende uitstroomcurves. Wij beschouwen de beschikbaarheid van deze referentiegegevens voor de verzuimduur per diagnose als een grote stap voorwaarts.? De referentiegegevens zijn bruikbaar voor bedrijfsartsen en anderen die een beeld willen krijgen van de te verwachten verzuimduur bij een specifieke aandoening.

Ten slotte willen we erop wijzen dat deze referentiegegevens niet beschouwd moeten worden als een prescriptieve norm. ${ }^{4.8}$ Het geeft een beschrijving van de te verwachten verzuimduur in de huidige praktijk in de jaren 2004 en 2005 en mag niet gebruikt worden om individuele werknemers die verzuimen onder druk te zetten om weer te gaan werken (omdat bijvoorbeeld 75\% van de werknemers met deze aandoening alweer volledig aan de slag is). Het geeft wel een signaal om nader te kijken wat er bij het individuele verzuimgeval speelt, waarbij u kunt denken aan oorzaken of redenen voor langduriger verzuim die niet worden gedekt door uitsluitend de betreffende diagnosecode.

\section{LITERATUUR}

I. Prezzia C, Denniston P. The use of evidence-based duration guidelines. J Worker Compensation 200I; IO(4).

2. Reed P (red.). The Medical Disability Advisor: Workplace Guidelines for Disability Duration, Fourth edition. Boulder, CO: The Reed Group, 200 I.

3. Korver A, Jettinghoff K, Smulders P, Stark K. Arbeid, transities en ziekteverzuim. TNO rapport I0284. Hoofddorp: TNO, 2004.

4. Gerven JHAM, Boer WEL de. Haalbaarheidsonderzoek naar een Nederlandse versie van de Medical Disability Advisor. TNO-rapport 25I3I. Hoofddorp: TNO, 2002.

5. CBS Nationale Verzuimstatistiek, www.cbs.nl/statline.

6. Boerdam A, Bloemendal C, Geertjes K. Eindrapport haalbaarheidsonderzoek naar arbeidsgerelateerd verzuim in de Nationale Verzuimstatistiek. Voorburg/ Heerlen: CBS, 2007.

7. Hoek $\mathrm{W}$ van der. Laboretum, een nieuw instrument voor bedrijfs- en verzekeringsartsen. Tijdschr Bedrijfs Verzekeringsgeneeskd 2007; I5(4): I84-I85.

8. Dam H. Arboretum. Tijdschr Bedrijfs Verzekeringsgeneeskd 2005; I3(8): 24 I. 